\title{
3 \\ En torno al debate sobre la noción de patrimonio
}

\section{Marie Tenier}

\section{La práctica patrimonial o patrimonialización}

La época contemporánea se caracteriza por lo que podemos llamar la patrimonialización generalizada. Casi todo hoy es susceptible de ser declarado objeto de salvaguardia o de preservación. Pueden ser los monumentos históricos como las casas tradicionales o coloniales, las ruinas incaicas, las grandes catedrales, las especies animales y vegetales, la cultura. La noción de patrimonio ha llegado hasta campos de estudio que incluyen la información por los genes. Esta manera de enfocar el concepto de patrimonio es probablemente la más reciente de sus numerosas definiciones. El "patrimonio" en el contexto de esta nota de investigación, sugiere una dimensión de apropiación de "bienes nacionales", de objetos calificados de "patrimoniales" a los cuales se les da una nueva significación de herencia. No es tanto lo que uno hereda desde un punto de vista de patrimonio "doméstico" o de padres a hijos -como lo sugiere el sentido común de la palabra-, sino que es un término más amplio que llegó a representar todo lo que puede ser testigo de una diferenciación o de una identidad, es decir cualquier cosa. En este sentido es difícil elaborar un cuadro de estudio apropiado para el estudio del patrimonio. Más bien enfocamos el patrimonio como fenómeno social altamente ligado al surgimiento de los problemas de identidad provocados por el desarrollo de la sociedad moderna, la cual nos muestra hasta qué punto la relación identidaria se quiebra en miles de pedazos a reconstruir continuamente hacia un futuro inseguro. El pensamiento histórico trastornó la visión del tiempo cíclico reemplazándolo por la idea de progreso que dejó al pasado en una condición de inconsecuencia para la actualidad.

\section{Práctica patrimonial y museográfica y la idea de tiempo}

Es importante interrogarse sobre este frenesí de la conservación que es reflejado por la 
práctica museográfica, pero que también sigue más allá con un nuevo acto de patrimonialización. Qué es lo que refleja esta nueva actitud y en qué se distingue de la estricta práctica de conservación difundida por el museo. Interrogándonos a propósito de la fulgurante expansión del fenómeno de conservación, lograremos entender un nuevo movimiento que impulsa el pasado en un futuro no sólo a conservar sino a mantener vivo.

La idea de patrimonio introduce un nuevo problema que también puede ser enfocado a partir del problema de la relación con el tiempo. El ejemplo del museo demuestra el objeto histórico, objeto testigo de un tiempo declarado muerto, de un pasado que fue objetivado, de un tiempo estudiado por la historia como disciplina científica que lo analizó, que lo objetivó y que lo declaró inalterable. En la práctica de la museografía el objeto elegido para la representación de un contexto histórico adquiere una característica particular en relación con el visitante o con el espectador. El pensamiento histórico, y sobre todo la historia como ciencia, actúa de un modo tal que el objeto es clasificado de manera que se le impone una visión histórica evolucionista que deja el objeto expuesto en una condición de cosa muerta. El objeto presentado en el museo adquiere un status de pasado, de un objeto sin vida, de un objeto para ser contemplado y que no tiene mayor impacto sobre la vida o la experiencia del espectador. Lo que es histórico, lo que representa de alguna manera la historia, aunque sea un hecho del contexto presente, perpetúa la imagen de un hecho pasado calificado de inconsecuente. Entonces, diríamos que el objeto del museo es estático, sin vida, sin ninguna influencia directa sobre el visitante. Sin embargo, el objeto de la exposición provoca reacciones de admiración y de contemplación que constituye un sentido que alimentará la reflexión identidaria tanto personal como colectiva.

\section{Patrimonio e historia}

La historia manifiesta una visión y construcción del pasado que no tiene peso para la actualidad. Como dice Dumont, el pasado demistificado ya no sive para interpretar $y$ justificar el presente. La historia se instituye como una ciencia que describe lo que ocurrió a partir de bases metodológicas científicas, todo con una preocupación de reconstrucción y conservación de la memoria. Esta disciplina, que sirve de base a todas las otras ciencias humanas, provoca una relación con el tiempo y las cosas que hemos tratado de demostrar con el ejemplo del museo. Este modelo nos permitió tipificar la relación del ser moderno con el tiempo y con las cosas que se impone en las márgenes de un tiempo lineal indudablemente orientado hacia el futuro. Esta relación demostrada por la museografía propone clasificar lo pasado para asegurar un sentimiento de memoria, conservar y archivar objetos representativos de lo que fuimos o de lo que otros fueron, visitar de vez en cuando nuestro reflejo de vida -el espejo de nuestra realidad en la imposición identidaria en el otro- captar elementos o símbolos que dibujarán, mantendrán y alimentarán una identidad que se modificará continuamente.

Es esta relación con el objeto o las cosas la que está en juego en el problema de la historia como ciencia que estudia el pasado y lo archiva en la memoria. Es también esta cuestión la que nos provocó una discusión a propósito del predominio del futuro en el pensamiento histórico; el pasado está muerto y el presente construye el futuro. Y no sólo el futuro sino una idea de proceso, de identidad a armar hacia un futuro modificable, orientable y mejorable.

Ahora bien, ¿de qué manera el concepto de patrimonio representa una nueva dimensión de la relación con el tiempo y con el objeto? De alguna manera, el patrimonio tiene su origen en las metas del museo, es decir que se puede fácilmente analizar como un continuo lógico de la nueva relación con el tiempo inaugurada con la ruptura de la Tradición hacia el pensamiento 
racional. En efecto, el movimiento provocado por la historia que tiende a conservar todo to que existe, que archiva pruebas o muestras del pasado, se demostró por esta tendencia representada por el museo y su carácter de conservación. Luego, analizando el patrimonio como un nuevo término o una nueva práctica que sigue los pasos del museo, se podrá descubrir una dimensión singular que no se puede soslayar.

Según mi modo de ver, el patrimonio es como una práctica que echa raíces en la misma relación de conservación demostrada por el museo pero que al mismo tiempo introduce una nueva relación. Sugiero la idea de André Micoud, que propone en el acto de patrimonialización, una nueva orientación de la acción. Los cambios ocurridos en la práctica reflejada por el patrimonio terminarán por orientarse no tanto hacia el pasado histórico conservado en el museo sino hacia un futuro reproducido y gestionado hacia el futuro. Para adelantar el problema diríamos que el objeto patrimonializado no será solamente conservado sino, esencialmente, salvaguardado.

Es esta última dimensión la que caracterizará nuestros propósitos. El patrimonio es más que la práctica de conservación generalizada provocada por una pérdida de memoria; más bien, estaríamos en presencia de un retorno hacia lo tradicional, o sea, de una actualización de la Tradición y de un nuevo trastorno en la relación con el tiempo. El patrimonio no sólo se desarrolla como agente de conservación sino de reproducción y de gestión que transforma el objeto antiguo en uno del presente y que a la vez es impulsado hacia adelante. ¿Qué significa esta nueva relación? Parece que estaríamos tratando de hacer revivir la Tradición. ¿Querríamos de alguna manera resucitar el pasado muerto?

Estas consideraciones sugieren muchas preguntas y provocan varios debates en cuanto a la relación con el tiempo, con la Tradición y también con los presupuestos que han dibujado el pensamiento moderno. La relación con las cosas cambiará fundamentalmente; el objeto "histórico" ya no será una pura muestra extraída de su medio ambiente para ser conservada y expuesta, sino más bien, el objeto declarado "patrimonio" se entenderá como un recurso, es decir como algo que sirve para una experiencia presente y seguramente para una necesidad futura. Esta intervención, que cambiará el objeto en recurso, necesitará una actitud administrativa para mantenerlo vivo e instituirlo como referencia identidaria. Se tratará de mantener su contexto de vivencia y se logrará reproducir bajo un programa de gestión de recursos. Y al límite de la cuestión patrimonial, se verá que esta gestión intentará, además de salvaguardar toda las cosas susceptibles de desaparecer y rescatar lo que está fosilizado, gestionar y poner en stock "todo lo que existe bajo el sol".

\author{
Marie Tenier \\ Facultad Sociología del Turismo \\ Universidad de Lancaster, Reino Unido
}

